\title{
STRUCTURE OF THALICSIMIDINE
}

Z. F. Ismailov, M. V. Telezhenetskaya, and S. Yu. Yunusov

Khimiya Prirodnykh Soedinenii, Vol. 4, No. 2, p. 136,1968

We have previously reported the isolation of an aporphine base from the roots of Thalictrum simplex L. [1]. The base proved to be new, and we called it thalicsimidine. It contains a $\mathrm{N}$-methyl and five methoxy groups. The molecular weight determined by mass spectroscopy is 385 . The fragmentation of the base (the mass spectra were taken on a $M K h-$ 1303 mass spectrometer at an energy of the ionizing electrons of $34 \mathrm{eV}$ with an ionizing current of $150 \mu \mathrm{a}$, at $130^{\circ} \mathrm{C}$ ) agrees with the data published for aporphines [2]. The mass spectrum of thalicsimidine has peaks of ions with $\mathrm{m} / \mathrm{e}^{385}\left(\mathrm{M}^{+}\right)$, $384(\mathrm{M}-1)^{+}, 370\left(\mathrm{M}-\mathrm{CH}_{3}\right)^{\dagger}, 354\left(\mathrm{M}-\mathrm{OCH}_{3}\right)^{\dagger}, 342\left(\mathrm{M}-\mathrm{CH}_{2}=\mathrm{N}-\mathrm{CH}_{3}\right)^{+}$. The last ion, by losing a methyl group, gives an ion with $\mathrm{m} / \mathrm{e} 327$, the loss of one methoxyl leads to an ion with $\mathrm{m} / \mathrm{e} 311$, and the loss of two methoxyls to an ion $\mathrm{m} / \mathrm{e} 280$. However, the peaks with $\mathrm{m} / \mathrm{e} 152$ and 165 found in the spectra of three aporphine bases [2] are not present in the spectrum of thalicsimidine. The strongest peaks are those with $\mathrm{m} / \mathrm{e} 57,56,55$, and 43 . Since the specific rotation of the base is less than $100^{\circ}$, the substituents in ring $B$ must be located at $\mathrm{C}-2$ and $\mathrm{C}-3$ [3].

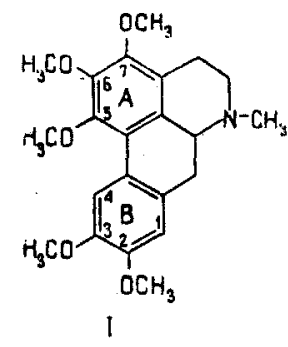

By analogy with other penta-substituted aporphines, we propose for thalicsimidine the structure I.

The NMR spectra of the base (taken by M. R. Yagudaev on a JNM-4H-100/100 MHz instrument in deuterochloroform) confirm the structure that we have proposed [4]. In the region of aromatic protons there are two one-proton singlets at $\delta 6.70$ and 7.89 , the latter relating to the hydrogen at $C-4$. The protons of $N$-methyl group appear in the form of a 3-proton singlet at $\delta 2.47$. The methoxy groups give four peaks at $\delta 3.88(\mathrm{C}-7), 3.85$ (two $\mathrm{OCH}_{3}$, at $\mathrm{C}-2$ and $\mathrm{C}-3$ ), $3.82(\mathrm{C}-6)$, and $3.64(\mathrm{C}-5)$.

\section{REFERENCES}

1. KTh, S. Umarov, M. V. Telezhenetskaya, Z. F. Ismailov, and S. Yu. Yunusov, KhPS [Chemistry of Natural Compounds], 3, 353, 1967.

2. M. Ohashi, J. Wilson, H. Budzikiewicz, M. Shamma, W. Slusarchyk, and C. Djerassi, J. Am. Chem. Soc., $85,2807,1959$.

3. S. Yu. Yunusov, DAN UzSSR, no. 8, 12, 1948.

4. N. Baarschers, R. Arndt, K. Pachler, I. Weisbach, and B. Douglas, J. Chem. Soc., 4778, 1964.

27 September 1967

Order of the Red Banner of Labor Institute of the Chemistry of Plant Substances, AS UzSSR

UDC $547.944 / 945$

\section{ALKALOIDS OF PEDICULARIS OLGAE}

A. Abdusamatov, Kh. Ubaev, and S. Yu. Yunusov

Khimiya Prirodnykh Soedinenii, Vol. 4, No. 2, pp. 136-137, 1968

Continuing our investigation of the alkaloids of $P$. olgae $[1,2]$, by chromatographing the ethereal fraction of the combined alkaloids on alumina (eluant: benzene-chloroform (2:1)], we have isolated a crystalline base with mp 188$189^{\circ} \mathrm{C}$ (ethanol), $R_{f} 0.77$ [1-butanol-water-acetic acid $(20: 20: 1)$ system], [a] ${ }^{20}+61.5^{\circ}$ (c $0.95 ;$ ethanol), $\mathrm{C}_{10} \mathrm{H}_{11} \mathrm{NO}$, 